\title{
Investigating students' Reflection of Learning experience and perception on achievement of Graduate capability in experiential Learning through an interdisciplinary project
}

\section{Lim You Ping, Dr. Loh Kah Heng, Theresa Chiew Gim Ean}

Taylor's University, Malaysia.

Correspondence Author: Lim You Ping, Taylor's University, Malaysia.

Received date: 12 January 2018, Accepted date: 25 June 2018, Online date: 21 July 2018

Copyright: (C) 2018 Lim You Ping et al. This is an open-access article distributed under the terms of the Creative Commons Attribution License, which permits unrestricted use, distribution, and reproduction in any medium, provided the original author and source are credited.

\begin{abstract}
Educators in higher education experience paradigm shift by adopting experiential education in engaging students in their learning process from conventional lecture system. Experiential learning enables students to acquire knowledge and skills through hand-on experiencing, particularly in interdisciplinary subject area. In line with the American education which require a student to take a wide variety of courses from different discipline, commonly known as general education: literature, science, the social sciences, the arts, history, and so forth prior to focusing on a specific field of study, a one-shot interdisciplinary project-based learning was conducted in Fall 2016 semester for students undertaking various subjects in American Degree Program (ADP) at Taylor's University, Malaysia. Lecturers in ADP believe that this project besides serving as an authentic purpose for the acquisition of knowledge and skills in most of the content area, it also promotes the acquisition of critical thinking skills and achieve the graduate capability as prescribed by Taylor's University on its students. The dependent variables were participants' reflection of learning experience, leadership ability and perception on achievement of Taylor's Graduate Capability (TGC). Participants were requested to answer an online questionnaire in Google sheets. The questionnaire consists of 5 points Likert scales survey questions with 54 items which capture the three dependent variables with high reliability, i.e. Cronbach Alpha of 0.972 . The collected data will be analyzed using statistical package, SPSS. Results from independent sample T-tests and Pearson Moment Correlation Coefficient showed that there is positive correlation between reflection of learning experience and achievement of TGC, and there is no statistical significant difference in the means of reflection of learning experience and perception on achievement of TGC between Freshmen and Sophomore participants. Result also show that participants who involved in organizing the AmFest: American Festival project (Group Leader) have very high positive correlation among their leadership capability, reflection of learning experience and achievement of TGC. The critical reflection from participants were collected and summarized to validate its consistency with the results obtain from statistical analysis.
\end{abstract}

Key words: Experiential learning, interdisciplinary project, Project-based learning, reflection of learning, graduate capability

\section{INTRODUCTION}

Educator in higher education has involved in a paradigm shift from traditional classroom teaching to experiential learning. Experiential education has become increasingly popular in higher education particularly in the interdisciplinary fields of study. The learning process is scaffolding through acquiring of knowledge and skills from experience. It is a method of educating through first-hand experience. Skills, knowledge, and experience are acquired outside of the traditional academic classroom setting. Various approaches are adopted in the experiential learning, such as Project-based learning (PBL) and Problem-based learning, internships, studies abroad, field trips, field research, and service-learning projects. According to Lewis and Williams [1] experiential learning means learning from experience or learning by doing. Experiential education first immerses learners in an experience and then encourages reflection about the experience to develop new skills, new attitudes, or new ways of thinking. Students will be the first and foremost beneficiary of experiential learning.

The philosophy underpinning the experiential education which may deem beneficial to learners include:

1. Experiential learning occurs when carefully chosen experiences are supported by reflection, critical analysis and synthesis.

2. Learner is actively engaged in posing questions, investigating, experimenting, being curious, solving problems, assuming responsibility, being creative, and constructing meaning.

3. Learners are engaged intellectually, emotionally, socially, soulfully and/or physically. This involvement produces a perception that the learning task is authentic.

4. The results of the learning are personal and form the basis for future experience and learning.

5. The design of the learning experience includes the possibility to learn from natural consequences, mistakes and successes.

Depending on the learner population, the benefits of experiential learning can increase. Learner groups that have been shown to benefit from experiential learning include 1) the learner who needs to personally experience the value of a subject in order to be motivated to learn 2) the learner who has trouble learning within the formal classroom and needs an alternate learning method in order to succeed and 3) any learner who can benefit from having hands-on examples to bolster their traditional learning [2].

This paper describes how interdisciplinary project work was introduced into American Degree Program at Taylor's University as an example of interdisciplinary project-based learning approach. We believe that this approach of learning will enable students to integrate knowledge obtained from other modules during the development of applicable projects - and eventually develop practical skills and competencies. 
Citation: Lim You Ping, Dr. Loh Kah Heng, Theresa Chiew Gim Ean, 2018. Investigating students' Reflection of Learning experience and perception on achievement of Graduate capability in experiential Learning through an interdisciplinary project. Advances in Natural and Applied Sciences., 12(7): 26-32.

Four Null Hypotheses were formulated to guide this research. They are:

$\mathrm{H}_{01}$ : There is no statistically significant correlation between participants' reflection of learning experience and perception on achievement of Taylor's graduate capability (TGC) after participating in the interdisciplinary project-based learning.

$\mathrm{H}_{02}$ : There is no significant difference in the reflection of learning experience between freshmen and sophomore participants after participating in the interdisciplinary project-based learning.

$\mathrm{H}_{03}$ : There is no significant difference in the perception on achievement of Taylor's Graduate Capability (TGC) between freshmen and Sophomore after participating in the interdisciplinary project-based learning.

$\mathrm{H}_{04}$ : There is no statistically significant correlation among reflection of learning experience, perception on achievement of Taylor's Graduate Capability and perception on leadership capability for project leaders after participating in the interdisciplinary project-based learning.

\section{Literature Review:}

In line with the call to prepare university students with employability, many universities have shifted from conventional classroom teaching approach to experiential education whereby students are empowered to develop knowledge, practical skills and competencies that will make them attractive to future employers. From the point of view of the university, experiential learning can help institutions stay relevant to students by providing them with the necessary skills to transition into the workforce. Cantor [2] believes that experiential learning enables higher education to more closely interface with business to promote community economic development.

B. Canboy, Montalvo, Buganza and Emmerling [3] has described a new module in the master program which help students to develop interdisciplinary projects using the framework of experiential learning theory. The new module showed an example of integration of interdisciplinary project-based learning systematically into a programme curriculum. The new module Known as Module 9, as described by B. Canboy et al. was redesigned to allocate time for extra seminars that follow the framework of ELT (English Language Teaching) and guide students step-by-step in their respective team projects and learning outcomes. Result show that every team experienced each learning mode and that collaborating with companies helped students learn about new realities. The general satisfaction with the course and the transferability of the projects to real workplaces were positively evaluated by students, professors and collaborating companies.

Vanashri and Lee [4] conducted an interdisciplinary project-based learning which integrated Science, Engineering Design and Mathematics for Grade 5 and Grade 6 students. The interdisciplinary PBL project allows students to learn about solid waste management, actively construct their ideas, and collaboratively engage in tasks that emphasize the connection of science and mathematical knowledge. Their PBL unit helps students understand the important environmental issue of solid waste management by engaging them in science and math concepts and challenges them to develop solutions for addressing this issue. This PBL unit was a great way to give students ownership to do something about the problem while learning science and math content knowledge and engaging in process skills.

Vanashri and John [5] collaborate with a high school social studies teacher to conduct an interdisciplinary PBL, the Stories of Inventions: An Interdisciplinary Project-Based Unit for U.S. History Students. The unit links scientific innovation to social context [6] which encouraged students to associate the second industrial revolution's many inventions (in such areas as manufacturing, transportation, and communication) with methodical investigation and professional collaboration rather than random eureka moments. The goal was to develop student understandings about the evolution of different inventions within their scientific and societal contexts. The unit culminated with students producing and presenting timelines of significant inventions from the period.

Caroline Sly [7] suggest that project-based learning, which is an approach to experiential education must not be viewed as the extension or add on to the project after the tradition instruction, instead, it must be viewed as the central to the curriculum. Due to its nature of "ill-structured" or challenging questions which may require complex thinking and skills, project-based learning is often interdisciplinary. Research shows that interdisciplinary project-based learning enhances critical thinking skills and fosters positive attitudes towards various subjects and improve performance with conceptual questions and applied problems. Caroline Sly [7] further explain that teachers who have used project-based learning have observed learners to have better attitudes toward learning, better work habits, improved problem-solving capabilities and more self-esteem.

\section{Methodology:}

This study applies mixed mode research method. The study yields quantitative data by examining a possible correlation among participants' reflection of learning experience, perception on achievement of Taylor's Graduate Capability and perception of leadership capability (for participants taking the group leaders responsibility only) after participating in the interdisciplinary project-based learning. Besides, the study also examine the difference in means for participants' reflection of learning experience and perception on achievement of Taylor's graduate capability between Freshmen and Sophomore participants.

The qualitative data from the critical reflection journal/ paragraph will be summarized to validate its consistency with the statistical analysis obtained from hypothesis testing.

AmFest: The interdisciplinary Project for PBL:

AmFest was an interdisciplinary effort organized by lecturers of five subjects together with students from various courses (Microeconomics, Macroeconomics, History, Sociology and Statistics) of American Degree Program at Taylor's University, Malaysia. This event aimed to promote the United States of America spirit within ADP, and to create awareness among students about the different cultures/histories, religions and social-economic status of America. Students were segregated according to their enrolled courses into 13 American cities (New York, Los Angeles, Chicago, Houston, Philadelphia, Phoenix, San Jose, San Francisco, Washington, Boston, Honolulu, Pittsburgh and Seattle).

The Interdisciplinary project which took place for almost the whole semester aims to educate the students about the history, cultural and social-economic of the United States of America with the following objectives:

- To provide interdisciplinary learning experiences among students through direct interaction and cross disciplines knowledge sharing.

- To allow students to view the poverty problems in various cities of the United States of America from different perspectives: histories, cultures, religions, social-economic and statistical analysis.

- To sharpen the soft skills of the organizers and participants involved.

The event to showcase the project outcome was held on a weekend of the semester to avoid clashing with other class. It started bright and early at $9.00 \mathrm{am}$. Each room was dressed from floor to ceiling with apt décor and exhaustive information. Ongoing evaluation, course-based and general evaluations were conducted by lecturers of various courses such as Economics, History, Sociology and Statistics throughout the event.

A treasure hunt entitled The Lost Cities of America which marks the central activity of the PBL encouraged students to obtain information from the exhibits. Participants were challenged to search and hunt the keywords and information around other cities based on the questions given, while racing against time with other teams. Several questions may test on general knowledge or their ability to identify answers in the scatter of information throughout the showcase within the limited time. This activity aimed to

- involve all students for an interdisciplinary learning as they go around and cross over cities in the United States of America

- $\quad$ encourage students work as a team to obtain information from other cities

- help students gain a firm understanding in the American cities

- learn the poverty and economic growth in various cities of the United States of America from different perspectives: histories, cultures, religions, social-economic and statistical analysis.

This creates room for learning to all students, whether before or during the event, as well as the lecturers.

\section{Participants:}

A total of 100 students undertaking various courses in American Degree Program in Fall 2016 semester participated in this project. Some of the students may be taking more than one course in the semester. A total of 65 students from various major responded to the online questionnaire. 


\section{Data Collection Tool:}

The dependent variables in this study were participants' reflection of learning experience, perception on leadership ability and achievement of Taylor's Graduate capability. Participants' reflection of learning experience was developed and designed to measure an individual's real or anticipated learning experience with regards to the cognitive, affective and process/psychomotor dimension in a 25 -item self-reporting, numerically measurable questionnaire. Perception on leadership ability will measure the leadership capability of participants who were also involved in organizing the interdisciplinary project with regards to planning, managing, communicating, coordinating and strategizing the project throughout the entire interdisciplinary project in a 12-item self-reporting, numerically measurable questionnaire. The perception on achievement of Taylor's Graduate Capability will capture participants' graduate capability with regards to their discipline-specific knowledge, Cognitive capabilities and soft skills in a 17-item self-reporting, numerically measure questionnaire. The questionnaires consist of 54 items of survey questions which are designed using 5 points Likert scales of strongly disagree, kind of disagree, kind of agree, agree and strongly agree with Cronbach Alpha of 0.972. This questionnaire was administered to all participants through online Google sheets, together with the critical reflection questions which required participants to write in short paragraphs.

\section{Data Analysis:}

The numerical data collected from online Google sheet will be transformed into SPSS data sheet and various statistical analysis such as independent sample T-Test and Pearson moment Correlation test will be performed using SPSS to test the hypotheses formulated in this study.

Results:

The Hypotheses which were formulated to guide this research will be tested in the following section.

Testing of Null Hypothesis $H_{01}$ :

$\mathrm{H}_{01}$ : There is no statistically significant correlation between participants' reflection of learning experience and perception on achievement of Taylor's graduate capability (TGC) after participating in the interdisciplinary project-based learning.

$\mathrm{H}_{01 \mathrm{a}}$ : There is no statistically significant correlation among participants' reflection of learning experience in cognitive, affective and psychomotor dimension and perception on achievement of TGC after participating in the interdisciplinary project-based learning.

$\mathrm{H}_{01 \mathrm{~b}}$ : There is no statistically significant correlation among participants' reflection of learning experience and perception on achievement of TGC with regards to discipline-specific knowledge, Cognitive capabilities and soft skills after participating in the interdisciplinary project-based learning.

A Pearson product-moment correlation coefficient was computed to assess correlation between the participants' reflection of learning experience and perception on achievement of Taylor's graduate capability after participating in the interdisciplinary project-based learning. There was a statistically significant positive correlation between these two variables, $\left(\mathrm{r}=0.865, \mathrm{n}=65, \mathrm{p}<.01\right.$, two-tailed). Thus, the null hypothesis $\mathrm{H}_{01}$ was rejected in favor of its alternative. Overall, there is a statistically significant and strong positive correlation between participants' reflection of learning experience and perception on achievement of Taylor's Graduate Capability (TGC) after participating in the interdisciplinary project-based learning. The statistical analysis revealed that higher reflection of learning experience corresponds to higher perception of achievement of TGC. that:

The Pearson Correlation coefficient test was also performed to test the associated subsidiary hypotheses. The correlation table shown in Table 1 indicated

[1] The Participants' Reflection of learning experience in cognitive, affective and psychomotor dimension and perception on achievement of Taylor's Graduate Capability (TGC) show a significant positive coefficient at alpha $<0.01$.

$\mathrm{H}_{01 \mathrm{a}}$ was thus rejected, and there is a statistically significant and strong positive correlation among participants' reflection of learning experience in cognitive, affective and physical dimension and perception on achievement of Taylor's graduate capability (TGC) after participating in the interdisciplinary project-based learning.

[2] The participants' reflection of learning experience and perception on achievement of Taylor's Graduate Capability (TGC) with regards to disciplinespecific knowledge, Cognitive capabilities and soft skills show a significant positive correlation at alpha $<0.01$.

$\mathrm{H}_{01 \mathrm{~b}}$ was rejected and there is a significant positive strong correlation among participants' reflection of learning experience and perception on achievement of Taylor's Graduate Capability (TGC) with regards to discipline-specific knowledge, Cognitive capabilities and soft skills after participating in the interdisciplinary project-based learning.

Table 1: Pearson's Moment Correlation coefficients for Reflection of learning experience and achievement of TGC

\begin{tabular}{|c|c|c|c|c|c|c|c|c|c|}
\hline \multicolumn{10}{|c|}{ Correlations } \\
\hline & & $\begin{array}{c}\text { Average } \\
\text { Cognitive } \\
\text { Dimension of } \\
\text { Learning } \\
\text { Experience } \\
\end{array}$ & $\begin{array}{l}\text { Average } \\
\text { Affective } \\
\text { Dimension of } \\
\text { Learning } \\
\text { Experience }\end{array}$ & $\begin{array}{c}\text { Average } \\
\text { Psychomotor } \\
\text { Dimension of } \\
\text { Learning } \\
\text { Experience } \\
\end{array}$ & $\begin{array}{l}\text { Average Total } \\
\text { Learning } \\
\text { Experience } \\
\end{array}$ & $\begin{array}{c}\text { Average } \\
\text { Discipline } \\
\text { specific } \\
\text { knowledge }\end{array}$ & $\begin{array}{c}\text { Average } \\
\text { Cognitive } \\
\text { Capabilities }\end{array}$ & $\begin{array}{c}\text { Average Soft } \\
\text { Skills }\end{array}$ & $\begin{array}{l}\text { Average Total } \\
\text { TGC score }\end{array}$ \\
\hline \multirow{3}{*}{$\begin{array}{l}\text { Average Cognitive } \\
\text { Dimension of Learning } \\
\text { Experience }\end{array}$} & Pearson Correlation & 1 & $.870^{\prime \prime}$ & $.833^{\prime \prime}$ & $.941^{\prime \prime}$ & $.750 "$ & $.743^{\prime \prime}$ & $.769^{\prime \prime}$ & $.809^{\prime \prime}$ \\
\hline & Sig. (2-tailed) & & .000 & .000 & .000 & .000 & .000 & .000 & .000 \\
\hline & $\mathrm{N}$ & 65 & 65 & 65 & 65 & 65 & 65 & 65 & 65 \\
\hline \multirow{3}{*}{$\begin{array}{l}\text { Average Affective } \\
\text { Dimension of Learning } \\
\text { Experience }\end{array}$} & Pearson Correlation & $.870^{\prime \prime}$ & 1 & $.845^{\prime \prime}$ & $.972^{m}$ & $.744^{\prime \prime}$ & $.771^{\prime \prime}$ & $.778^{\mathrm{m}}$ & $.822^{\prime \prime}$ \\
\hline & Sig. (2-tailed) & .000 & & .000 & .000 & .000 & .000 & .000 & .000 \\
\hline & $\mathrm{N}$ & 65 & 65 & 65 & 65 & 65 & 65 & 65 & 65 \\
\hline \multirow{3}{*}{$\begin{array}{l}\text { Average Psychomotor } \\
\text { Dimension of Learning } \\
\text { Experience }\end{array}$} & Pearson Correlation & $.833^{\prime \prime}$ & $.845^{\prime \prime}$ & 1 & $.926^{m+}$ & $.689^{\prime \prime}$ & $.750^{\prime \prime}$ & $.844^{\prime \prime}$ & $.839^{\prime \prime}$ \\
\hline & Sig. (2-tailed) & .000 & .000 & & .000 & .000 & .000 & .000 & .000 \\
\hline & $\mathrm{N}$ & 65 & 65 & 65 & 65 & 65 & 65 & 65 & 65 \\
\hline \multirow{3}{*}{$\begin{array}{l}\text { Average Total Learning } \\
\text { Experience }\end{array}$} & Pearson Correlation & $.941^{\prime \prime}$ & $.972^{\mathrm{N}}$ & $.926^{\prime \prime}$ & 1 & $.769^{\prime \prime}$ & $.796^{\prime \prime}$ & $.833^{m "}$ & $.865^{\prime \prime}$ \\
\hline & Sig. (2-tailed) & .000 & .000 & .000 & & .000 & .000 & .000 & .000 \\
\hline & $\mathrm{N}$ & 65 & 65 & 65 & 65 & 65 & 65 & 65 & 65 \\
\hline \multirow{3}{*}{$\begin{array}{l}\text { Average Discipline } \\
\text { specific knowledge }\end{array}$} & Pearson Correlation & $.750^{\prime \prime}$ & $.744^{11}$ & $.689^{\prime \prime}$ & $.769^{\prime \prime}$ & 1 & $.765^{\prime \prime}$ & $.743^{\mathrm{m}}$ & $.853^{\mathrm{m}}$ \\
\hline & Sig. (2-tailed) & .000 & .000 & .000 & .000 & & .000 & .000 & .000 \\
\hline & $\mathrm{N}$ & 65 & 65 & 65 & 65 & 65 & 65 & 65 & 65 \\
\hline \multirow{3}{*}{$\begin{array}{l}\text { Average Cognitive } \\
\text { Capabilities }\end{array}$} & Pearson Correlation & $.743^{\mathrm{m}}$ & $.771^{\mathrm{m}}$ & $.750^{\prime \prime \prime}$ & $.796^{\mathrm{m}}$ & $.765^{\prime \prime}$ & 1 & $.847^{\mathrm{m}}$ & $.938^{\mathrm{m}}$ \\
\hline & Sig. (2-tailed) & .000 & .000 & .000 & .000 & .000 & & .000 & .000 \\
\hline & $\mathrm{N}$ & 65 & 65 & 65 & 65 & 65 & 65 & 65 & 65 \\
\hline \multirow[t]{3}{*}{ Average Soft Skills } & Pearson Correlation & $.769^{\prime \prime}$ & $.778^{\mathrm{N \prime}}$ & $.844^{\prime \prime \prime}$ & $.833^{\mathrm{m}}$ & $.743^{\mathrm{m}}$ & $.847^{\prime \prime}$ & 1 & $.967^{m}$ \\
\hline & Sig. (2-tailed) & .000 & .000 & .000 & .000 & .000 & .000 & & .000 \\
\hline & $\mathrm{N}$ & 65 & 65 & 65 & 65 & 65 & 65 & 65 & 65 \\
\hline \multirow[t]{3}{*}{ Average Total TGC score } & Pearson Correlation & $.809^{\prime \prime}$ & $.822^{\mathrm{m}}$ & $.839^{\prime \prime}$ & $.865^{m}$ & $.853^{\mathrm{N}}$ & $.938^{\prime \prime}$ & $.967^{\mathrm{Nm}}$ & 1 \\
\hline & Sig. (2-tailed) & .000 & .000 & .000 & .000 & .000 & .000 & .000 & \\
\hline & $\mathrm{N}$ & 65 & 65 & 65 & 65 & 65 & 65 & 65 & 65 \\
\hline
\end{tabular}


Testing of Null Hypothesis $\mathrm{H}_{02}$ :

$\mathrm{H}_{02}$ : There is no significant difference in the reflection of learning experience between freshmen and sophomore participants after participating in the interdisciplinary project-based learning.

$\mathrm{H}_{02 a}$ : There is no significant difference in the cognitive dimension of reflection of learning experience between freshmen and sophomore participants after participating in the interdisciplinary project-based learning.

$\mathrm{H}_{02 b}$ : There is no significant difference in the affective dimension of reflection of learning experience between freshmen and sophomore participants after participating in the interdisciplinary project-based learning.

$\mathrm{H}_{02 \mathrm{c}}$ : There is no significant difference in the psychomotor dimension of reflection of learning experience between freshmen and sophomore participants after participating in the interdisciplinary project-based learning.

An independent samples T-test was performed on the mean of reflection of learning experience for all participants. As indicated in the independent samples test statistics shown in Table 2, the p-value is more than 0.05, the null hypothesis cannot be rejected. The following results are reported based on the Independent samples t-test statistics

$\mathrm{H}_{02}$ : There was no significant difference in the mean of reflection of learning experience for Freshmen participants $(M=3.76, \mathrm{SD}=0.70)$ and Sophomore participants $(\mathrm{M}=3.64, \mathrm{SD}=0.80) ; \mathrm{t}(63)=0.62, \mathrm{p}=0.538$.

The independent samples T-test was performed on the mean of reflection of learning experience for all participants in Cognitive, Affective and Psychomotor dimension. As indicated in the independent samples t-test statistics shown in Table 2, the p-values are more than 0.05 for each of the separate test, this indicates that the subsidiary null hypotheses associated to the primary null hypothesis $\left(\mathrm{H}_{02}\right)$ cannot be rejected. The following results are reported based on the Independent samples t-test statistics.

$\mathrm{H}_{022}$ : There was no significant difference in the mean score of Reflection of learning experience in cognitive dimension for Freshmen participants ( $M=3.75$, $\mathrm{SD}=0.68)$ and Sophomore participants $(\mathrm{M}=3.59, \mathrm{SD}=0.83) ; \mathrm{t}(63)=0.83, \mathrm{p}=0.410$

$\mathrm{H}_{02 b}$ : There was no significant difference in the mean score of Reflection of learning experience in affective dimension for Freshmen participants (M=3.60, $\mathrm{SD}=0.83)$ and Sophomore participants $(\mathrm{M}=3.52, \mathrm{SD}=0.88) ; \mathrm{t}(63)=0.375, \mathrm{p}=0.709$

$\mathrm{H}_{02 c}$ : There was no significant difference in the mean score of Reflection of learning experience in psychomotor dimension for Freshmen participants $(\mathrm{M}=4.02, \mathrm{SD}=0.70)$ and Sophomore participants $(\mathrm{M}=3.89, \mathrm{SD}=0.75) ; \mathrm{t}(63)=0.734, \mathrm{p}=0.466$.

These results suggest that after participating in the interdisciplinary project, the mean of reflection of learning experience for both Freshmen and Sophomore participants in all the three dimensions are no difference. This imply that the year of study in the ADP Program does not affect the mean of reflection of learning experience, hence this has indicated that there is learning taking place as indicated by the means of learning experience which are above 3.5 out of 5 , as long as they participate in this experiential learning.

Table 2: Independent samples T-test statistics for Reflection of learning experience

\begin{tabular}{|c|c|c|c|c|c|}
\hline \multicolumn{6}{|c|}{ Group Statistics } \\
\hline & year of study & $\mathrm{N}$ & Mean & Std. Deviation & $\begin{array}{c}\text { Std. Error } \\
\text { Mean }\end{array}$ \\
\hline \multirow{2}{*}{$\begin{array}{l}\text { Average Total Learning } \\
\text { Experience }\end{array}$} & Freshmen & 26 & 3.7615 & .70131 & .13754 \\
\hline & Sophomore & 39 & 3.6421 & .79873 & .12790 \\
\hline \multirow{2}{*}{$\begin{array}{l}\text { Average Cognitive } \\
\text { Dimension of Learning } \\
\text { Experience }\end{array}$} & Freshmen & 26 & 3.7527 & .68160 & .13367 \\
\hline & Sophomore & 39 & 3.5897 & .83246 & .13330 \\
\hline \multirow{2}{*}{$\begin{array}{l}\text { Average Affective } \\
\text { Dimension of Learning } \\
\text { Experience }\end{array}$} & Freshmen & 26 & 3.6014 & .82565 & .16192 \\
\hline & Sophomore & 39 & 3.5198 & .88188 & .14121 \\
\hline \multirow{2}{*}{$\begin{array}{l}\text { Average Psychomotor } \\
\text { Dimension of Learning } \\
\text { Experience }\end{array}$} & Freshmen & 26 & 4.0220 & .69716 & .13672 \\
\hline & Sophomore & 39 & 3.8864 & .75035 & .12015 \\
\hline
\end{tabular}

\begin{tabular}{|c|c|c|c|c|c|c|c|c|c|}
\hline \multicolumn{10}{|c|}{ Independent Samples Test } \\
\hline & \multicolumn{2}{|c|}{$\begin{array}{l}\text { Levene's Test for Equality of } \\
\text { Variances }\end{array}$} & \multicolumn{7}{|c|}{ t-test for Equality of Means } \\
\hline & \multirow[b]{2}{*}{$\mathrm{F}$} & \multirow[b]{2}{*}{ Sig. } & \multirow[b]{2}{*}{$\mathrm{t}$} & \multirow[b]{2}{*}{ df } & \multirow[b]{2}{*}{ Sig. (2-tailed) } & \multirow{2}{*}{$\begin{array}{c}\text { Mean } \\
\text { Difference }\end{array}$} & \multirow{2}{*}{$\begin{array}{l}\text { Std. Error } \\
\text { Difference }\end{array}$} & \multicolumn{2}{|c|}{$\begin{array}{l}\text { 95\% Confidence Interval of the } \\
\text { Difference }\end{array}$} \\
\hline & & & & & & & & Lower & Upper \\
\hline $\begin{array}{l}\text { Equal variances } \\
\text { assumed }\end{array}$ & \multirow[t]{2}{*}{.474} & \multirow[t]{2}{*}{.493} & .620 & 63 & .538 & .11949 & .19282 & -.26583 & .50480 \\
\hline $\begin{array}{l}\text { Equal variances not } \\
\text { assumed }\end{array}$ & & & .636 & 58.267 & .527 & 11949 & .18782 & -.25643 & 49541 \\
\hline $\begin{array}{l}\text { Equal variances } \\
\text { assumed }\end{array}$ & \multirow[t]{2}{*}{.665} & \multirow[t]{2}{*}{.418} & .830 & 63 & .410 & .16300 & .19650 & -.22967 & .55568 \\
\hline $\begin{array}{l}\text { Equal variances not } \\
\text { assumed }\end{array}$ & & & .863 & 60.248 & .391 & .16300 & .18878 & -.21458 & .54059 \\
\hline $\begin{array}{l}\text { Equal variances } \\
\text { assumed }\end{array}$ & \multirow[t]{2}{*}{.046} & \multirow[t]{2}{*}{.830} & .375 & 63 & .709 & .08159 & .21774 & -35353 & .51670 \\
\hline $\begin{array}{l}\text { Equal variances not } \\
\text { assumed }\end{array}$ & & & .380 & 56.129 & .706 & .08159 & .21485 & -34879 & .51196 \\
\hline $\begin{array}{l}\text { Equal variances } \\
\text { assumed }\end{array}$ & \multirow[t]{2}{*}{.205} & \multirow[t]{2}{*}{.652} & .734 & 63 & .466 & .13553 & .18475 & -.23366 & .50473 \\
\hline $\begin{array}{l}\text { Equal variances not } \\
\text { assumed }\end{array}$ & & & .745 & 56.396 & .460 & .13553 & .18202 & -.22904 & .50010 \\
\hline
\end{tabular}

Testing of Null Hypothesis $H_{03}$ :

$\mathrm{H}_{03}$ : There is no significant difference in the perception on achievement of Taylor's Graduate Capability (TGC) between freshmen and Sophomore after participating in the interdisciplinary project-based learning.

$\mathrm{H}_{03 \mathrm{a}}$ : There is no significant difference in the perception on achievement of TGC with regards to discipline specific knowledge between freshmen and Sophomore after participating in the interdisciplinary project-based learning.

$\mathrm{H}_{03 \mathrm{~b}}$ : There is no significant difference in the perception on achievement of TGC with regards to cognitive capability between freshmen and Sophomore after participating in the interdisciplinary project-based learning. 
$\mathrm{H}_{03 \mathrm{c}}$ There is no significant difference in the perception on achievement of TGC with regards to soft skills between freshmen and Sophomore after participating in the interdisciplinary project-based learning.

An independent samples T-test was performed on the mean score of perception of achievement of Taylor's Graduate Capability for all participants. As indicated in the independent samples t-test statistics shown in Table 3 , the p-value is more than 0.05 , the null hypothesis cannot be rejected. The following results are reported based on the Independent samples t-test statistics

$\mathrm{H}_{03}$ : There was no significant difference in the mean score of perception on achievement of Taylor's Graduate Capability for Freshmen participants (M=3.99, $\mathrm{SD}=0.75)$ and Sophomore participants $(\mathrm{M}=3.83, \mathrm{SD}=0.68) ; \mathrm{t}(63)=0.899, \mathrm{p}=0.372$.

The independent samples T-test was performed on the mean score of perception of achievement of Taylor's Graduate Capability for all participants with regards to discipline specific knowledge, Cognitive capability and soft skills between freshmen and Sophomore after participating in the interdisciplinary projectbased learning. As indicated in the independent samples t-test statistics shown in Table 3, the p-values are more than 0.05 for each of the separate test, this indicates that the subsidiary null hypotheses associated to the primary null hypothesis $\left(\mathrm{H}_{03}\right)$ cannot be rejected. The following results are reported based on the Independent samples t-test statistics:

$\mathrm{H}_{03 a}$ : There was no significant difference in the mean score perception of achievement of Taylor's Graduate Capability with regards to discipline specific knowledge for Freshmen participants $(M=3.76, S D=0.92)$ and Sophomore participants $(M=3.65, S D=0.75) ; t(63)=0.516, p=0.608$

$\mathrm{H}_{03 \mathrm{~b}}$ : There was no significant difference in the mean score of perception of achievement of Taylor's Graduate Capability with regards to Cognitive capability for Freshmen participants $(M=4.05, \mathrm{SD}=0.84)$ and Sophomore participants $(\mathrm{M}=3.92, \mathrm{SD}=0.74) ; \mathrm{t}(63)=0.647, \mathrm{p}=0.520$

$\mathrm{H}_{03 \mathrm{c}}$ : There was no significant difference in the mean score of perception of achievement of Taylor's Graduate capability with regards to soft skills for Freshmen participants $(\mathrm{M}=4.03, \mathrm{SD}=0.73)$ and Sophomore participants $(\mathrm{M}=3.83, \mathrm{SD}=0.72) ; \mathrm{t}(63)=1.08, \mathrm{p}=0.285$.

These results suggest that after participating in the interdisciplinary project, the mean of perception on achievement of Taylor's Graduate capability with regards to discipline specific knowledge, Cognitive capability and soft skills for both freshmen and Sophomore participants are no difference. This imply that the year of study in the ADP Program does not affect the perception on achievement of Taylor's Graduate capability. As the means are approximate close to 4, they have agreed on the achievement of TGC after participating in the interdisciplinary project. Hence this has indicated that TGC will be achieved as long as they participate in this experiential learning.

Table 3: Independent samples T-test for achievement of TGC

\begin{tabular}{|c|c|c|c|c|}
\hline \multicolumn{5}{|c|}{ Group Statistics } \\
\hline year of study & $\mathrm{N}$ & Mean & Std. Deviation & $\begin{array}{l}\text { Std. Error } \\
\text { Mean }\end{array}$ \\
\hline Freshmen & 26 & 3.9864 & .74857 & .14681 \\
\hline Sophomore & 39 & 3.8250 & 68247 & 10928 \\
\hline Freshmen & 26 & 3.7564 & 91679 & .17980 \\
\hline Sophomore & 39 & 3.6496 & .74515 & 11932 \\
\hline Freshmen & 26 & 4.0462 & .83773 & .16429 \\
\hline Sophomore & 39 & 3.9179 & .74370 & .11909 \\
\hline Freshmen & 26 & 4.0299 & .73337 & .14383 \\
\hline Sophomore & 39 & 3.8319 & .71867 & .11508 \\
\hline
\end{tabular}

\begin{tabular}{|c|c|c|c|c|c|c|c|c|c|c|}
\hline \multicolumn{11}{|c|}{ Independent Samples Test } \\
\hline & & \multicolumn{2}{|c|}{$\begin{array}{l}\text { Levene's Test for Equality of } \\
\text { Variances }\end{array}$} & \multicolumn{7}{|c|}{ t-test for Equality of Means } \\
\hline & & \multirow[b]{2}{*}{$\mathrm{F}$} & \multirow[b]{2}{*}{ Sig. } & \multirow[b]{2}{*}{$t$} & \multirow[b]{2}{*}{ df } & \multirow[b]{2}{*}{ Sig. (2-tailed) } & \multirow{2}{*}{$\begin{array}{c}\text { Mean } \\
\text { Difference }\end{array}$} & \multirow{2}{*}{$\begin{array}{l}\text { Std. Error } \\
\text { Difference }\end{array}$} & \multicolumn{2}{|c|}{$\begin{array}{l}95 \% \text { Confidence Interval of the } \\
\text { Difference }\end{array}$} \\
\hline & & & & & & & & & Lower & Upper \\
\hline \multirow[t]{2}{*}{ Average Total TGC score } & $\begin{array}{l}\text { Equal variances } \\
\text { assumed }\end{array}$ & .202 & .655 & .899 & 63 & .372 & .16139 & .17962 & -.19755 & .52033 \\
\hline & $\begin{array}{l}\text { Equal variances not } \\
\text { assumed }\end{array}$ & & & .882 & 50.234 & .382 & .16139 & .18302 & -20617 & .52894 \\
\hline \multirow[t]{2}{*}{$\begin{array}{l}\text { Average Discipline } \\
\text { specific knowledge }\end{array}$} & $\begin{array}{l}\text { Equal variances } \\
\text { assumed }\end{array}$ & 2.908 & .093 & .516 & 63 & .608 & .10684 & .20700 & -30682 & .52050 \\
\hline & $\begin{array}{l}\text { Equal variances not } \\
\text { assumed }\end{array}$ & & & .495 & 46.000 & .623 & .10684 & .21579 & -.32752 & .54120 \\
\hline \multirow[t]{2}{*}{$\begin{array}{l}\text { Average Cognitive } \\
\text { Capabilities }\end{array}$} & $\begin{array}{l}\text { Equal variances } \\
\text { assumed }\end{array}$ & .796 & .376 & .647 & 63 & .520 & .12821 & .19808 & -.26763 & .52404 \\
\hline & $\begin{array}{l}\text { Equal variances not } \\
\text { assumed }\end{array}$ & & & .632 & 49.231 & .530 & .12821 & .20291 & -.27951 & .53592 \\
\hline \multirow[t]{2}{*}{ Average Soft Skills } & $\begin{array}{l}\text { Equal variances } \\
\text { assumed }\end{array}$ & .004 & .947 & 1.079 & 63 & .285 & .19801 & .18344 & -.16857 & .56459 \\
\hline & $\begin{array}{l}\text { Equal variances not } \\
\text { assumed }\end{array}$ & & & 1.075 & 52.973 & .287 & .19801 & .18420 & -.17145 & .56747 \\
\hline
\end{tabular}

Testing of Null Hypothesis $H_{04}$ :

$\mathrm{H}_{04}$ : There is no statistically significant correlation among reflection of learning experience, perception on achievement of Taylor's Graduate Capability and perception on leadership capability for project leaders after participating in the interdisciplinary project-based learning.

$\mathrm{H}_{04 a}$ : There is no statistically significant correlation between reflection of learning experience and perception on leadership capability for project leaders after participating in the interdisciplinary project-based learning.

$\mathrm{H}_{04 \mathrm{~b}}$ : There is no statistically significant correlation between perception on achievement of Taylor's Graduate Capability and perception of leadership capability for project leaders after participating in the interdisciplinary project-based learning. 
$\mathrm{H}_{04 c}$ : There is no statistically significant correlation among reflection of learning experience, and perception on achievement of Taylor's Graduate Capability for project leaders after participating in the interdisciplinary project-based learning.

The Pearson Correlation coefficient test was also performed to test the associated subsidiary hypotheses. The correlation table shown in Table 4 indicated that:

a) A Pearson product-moment correlation coefficient was computed to assess correlation between the reflection of learning experience and perception on leadership capability for group leaders after participating in the interdisciplinary project-based learning. There was a statistically significant positive correlation between these two variables, $(r=0.829, \mathrm{n}=14, \mathrm{p}<.01$, two-tailed $)$. Thus, the subsidiary null hypothesis $\mathrm{H}_{04 \mathrm{a}}$ was rejected in favor of its alternative. Overall, there is a statistically significant strong positive correlation between reflection of learning experience and perception of leadership capability for group leaders after participating in the interdisciplinary project-based learning. The statistical analysis revealed that higher reflection of learning experience corresponds to higher perception on leadership capability.

b) A Pearson product-moment correlation coefficient was computed to assess correlation between perception on achievement of Taylor's Graduate Capability and perception of leadership capability for group leaders after participating in the interdisciplinary project-based learning. There was a statistically significant positive correlation between these two variables, $\left(\mathrm{r}=0.699, \mathrm{n}=14, \mathrm{p}<.01\right.$, two-tailed). Thus, the subsidiary null hypothesis $\mathrm{H}_{04 \mathrm{~b}}$ was rejected in favor of its alternative. Overall, there is a statistically significant strong positive correlation between perception on achievement of Taylor's Graduate Capability and leadership capability after participating in the interdisciplinary project-based learning. The statistical analysis revealed that higher perception on achievement of Taylor's Graduate capability corresponds to higher leadership capability

c) A Pearson product-moment correlation coefficient was computed to assess correlation between reflection of learning experience, and perception on achievement of Taylor's Graduate Capability for group leaders after participating in the interdisciplinary project-based learning. There was a statistically significant positive correlation between these two variables, $\left(\mathrm{r}=0.859, \mathrm{n}=14, \mathrm{p}<.01\right.$, two-tailed). Thus, the subsidiary null hypothesis $\mathrm{H}_{04 \mathrm{c}}$ was rejected in favor of its alternative. Overall, there is a statistically significant strong positive correlation between reflection of learning experience, and perception on achievement of Taylor's Graduate Capability after participating in the interdisciplinary project-based learning. The statistical analysis revealed that higher perception of Reflection of learning experience corresponds to higher leadership capability

Since all the subsidiary null hypotheses in the primary Null hypothesis $\mathrm{H}_{04}$ were rejected in favor of the alternative subsidiary hypotheses, the primary null hypothesis is rejected in favor of the alternative hypothesis, i.e.

Overall, there is a statistically strong significant correlation among reflection of learning experience, perception on achievement of Taylor's Graduate Capability and perception on leadership capability for group leaders after participating in the interdisciplinary project-based learning. The statistical analysis revealed that higher leadership capability corresponds to higher perception on achievement of Taylor's Graduate Capability and reflection of learning experience.

Table 4: Pearson's Moment Correlation coefficients for Reflection of learning experience and achievement of TGC for group leaders

\begin{tabular}{|l|l|r|r|}
\hline \multicolumn{4}{|c|}{ Descriptive Statistics } \\
\hline \multicolumn{1}{|c|}{} & Mean & Std. Deviation & \multicolumn{1}{|c|}{$\mathrm{N}$} \\
\hline Average Leadership & 4.0893 & .65000 & 14 \\
capability & & & \\
Average Total TGC score & 4.1975 & .58077 & 14 \\
Average Total Learning & 4.0686 & .56990 & 14 \\
Experience & & & \\
\hline
\end{tabular}

\begin{tabular}{|c|c|c|c|c|}
\hline \multicolumn{5}{|c|}{ Correlations } \\
\hline & & $\begin{array}{c}\text { Average } \\
\text { Leadership } \\
\text { capability }\end{array}$ & $\begin{array}{l}\text { Average Total } \\
\text { TGC score }\end{array}$ & $\begin{array}{l}\text { Average Total } \\
\text { Learning } \\
\text { Experience }\end{array}$ \\
\hline \multirow{3}{*}{$\begin{array}{l}\text { Average Leadership } \\
\text { capability }\end{array}$} & Pearson Correlation & 1 & $.699^{\prime \prime}$ & $.829^{\prime \prime}$ \\
\hline & Sig. (2-tailed) & & .005 & .000 \\
\hline & $N$ & 14 & 14 & 14 \\
\hline \multirow[t]{3}{*}{ Average Total TGC score } & Pearson Correlation & $.699^{\mathrm{n}}$ & 1 & $.859^{\mathrm{m}}$ \\
\hline & Sig. (2-tailed) & .005 & & .000 \\
\hline & $N$ & 14 & 14 & 14 \\
\hline \multirow{3}{*}{$\begin{array}{l}\text { Average Total Learning } \\
\text { Experience }\end{array}$} & Pearson Correlation & $.829^{\mathrm{m}}$ & $.859^{\mathrm{m}}$ & 1 \\
\hline & Sig. (2-tailed) & .000 & .000 & \\
\hline & $\mathrm{N}$ & 14 & 14 & 14 \\
\hline
\end{tabular}

Qualitative Analysis:

Critical reflection forms the integral part of an experiential learning. It is an essential process for transforming experiences gained from the interdisciplinary project and the course material into genuine learning. Three main critical reflection summarize from participants are listed below:

1) Participants' Cognitive aspect of critical reflection

Participants strongly agreed that team dynamic is the most significant gain from the project. They enjoyed working together with various people from different courses as they contributed interesting ideas and themes that were built into the final showcase. They did acquire the necessary knowledge with regards to various courses involved, particularly the economic and statistics aspect of US cities under their study. Participants agreed that this PBL has created a platform which allowed them to think critically, to voice out their opinions and put creativity into real life. Every students unleashed their problem solving skills through creativity and decoration on the showcase venue with limited supplies and information. Beside acquired new knowledge outside the traditional classroom setting, 
they agreed that this interdisciplinary project has also opened up a window for new friendships and betterment on participants' social and communication skills. It also created opportunities to assume leadership and have gained experience on leadership responsibilities.

2) Participants affective aspect of critical reflection

Some participants felt that the critical challenge throughout this interdisciplinary project was the difficulty in communication with students of various courses (economics, history and sociology). It was time consuming and stressful to find all information, interpret, analyze and compile all information in-line with the common themes from different perspectives. They encounter more challenges with lack of cooperation and coordination among group members.

Participants were unhappy with the evaluation method as most of them felt that the evaluation rubrics for this interdisciplinary project was not disclose to participants prior to the showcase. The same marks assigned to each student has discouraged them to put in effort. Challenges being more crucial when the group leaders were incompetence in handling their tasks. Lack of information and guidance from group leaders have caused the self-efficacy of the group to reduce and failed to meet the expectation set by the evaluators.

3) Participants' Psychomotor aspect of critical reflection with suggestion for improvement

Participants agreed that this interdisciplinary project provided an incredible learning experience and have generated great value for the stakeholders. They suggested to hold this event annually with a general theme for the interdisciplinary project so that students from more courses can collaborate and participate to maximize the benefit to students. They also suggested to make the interdisciplinary project an open/public event in order for all students from Taylor's University and high schools students to participate and learn from other courses. It will be ideal if each group composes the same number of students.

Participants proposed to hold interview session for the selection of group leader to ensure the competence and efficient group leader for each group. Since Interdisciplinary project required great effort and time consuming, therefore participants suggested to place a higher weightage of the mark allocation, at least $30 \%$ of the total mark.

\section{Discussion:}

This interdisciplinary project-based learning provides an experiential learning which allows students to do research about the poverty issues in the various cities in USA and gaining subject specific contents. They were also learning the presentation skills through this PBL by presenting valuable information to the public, which appears as the skills essential to the 21st century information age. The PBL enables them to learn how to harness the best out of their limited resources by using recycled items, sharing resources and being creative throughout. They utilized skills they learnt in other ADP courses, including speech, drama such as live statues and English composition. Working under tremendous time pressure, students excelled with what they do best, having fun while learning at the same time.

\section{Conclusion:}

Integrating the quantitative data from statistical analysis and transcript of qualitative data in this mixed mode approach enables researchers to validate the research results from both method. The independent samples T-test revealed that there were no significant difference in the mean of reflection of learning experience for Freshmen participants $(\mathrm{M}=3.76, \mathrm{SD}=0.70)$ and Sophomore participants $(\mathrm{M}=3.64, \mathrm{SD}=0.80) ; \mathrm{t}(63)=0.62, \mathrm{p}=0.528$. And, there was no significant difference in the mean of perception on achievement of Taylor's Graduate Capability for Freshmen participants $(\mathrm{M}=3.99$, $\mathrm{SD}=0.75)$ and Sophomore participants $(\mathrm{M}=3.83, \mathrm{SD}=0.68) ; \mathrm{t}(63)=0.899, \mathrm{p}=0.372$. Since both group recorded the means of reflection of learning experience and perception on achievement of TGC above 3.5, this indicated that they did agree to have gained learning experience and achieved the TGC in this experiential learning. The critical reflection from participants also translated to the same outcome, i.e they agreed to achieve learning after participating the project. Pearson's product moment tests indicated that there was a statistically significant positive correlation between reflection of learning experience and perception on achievement of TGC $(r=0.865, \mathrm{n}=65, \mathrm{p}<$ .01 , two-tailed)

Besides that, descriptive statistics for group leaders shows high means (above 4.0) for reflection in learning experience, perception on achievement of TGC and leadership capability which indicated they have agreed on their learning experience, achievement of TGC and leadership capability through this experiential learning. Correlation table also show that group leaders have higher perception on leadership capability which also corresponds to higher perception on achievement of Taylor's Graduate capability and reflection of learning experience after taking on leadership responsibility in organizing the project. This result indicates that more students should be granted opportunity for leadership responsibility and get involve in the organizing of the interdisciplinary project in order to boast up their learning experience and achievement of TGC.

\section{REFERENCES}

[1] Lewis, L.H. and C.J. Williams, 1994. In Jackson, L. \& Caffarella, R.S. (Eds.). Experiential Learning: A New Approach (pp. 5-16). San Francisco: JosseyBass.

[2] Cantor, J.A., 1995. Experiential Learning in Higher Education. Washington, D.C.: ASHEERIC Higher Education Report No. 7.

[3] Basak Canboy, Adolfo Montalvo, M. Carmen Buganza and Robert J. Emmerling, 2016. 'Module 9': a new course to help students develop interdisciplinary projects using the framework of experiential learning theory, Innovations in Education and Teaching International, 53(4): 445-457, DOI: $10.1080 / 14703297.2014 .975150$

[4] Nargund-Joshi, V., J.S. Lee, 2013. "How much Trash Do you Trash" Science and Children, 50(7): 50.

[5] Nargund-Joshi, V., J. Bragg, 2017. The Stories of Inventions: An Interdisciplinary, Project-Based Unit for US History Students the Science Teacher, 84(5): 44.

[6] Larmer, J., J.R. Mergendoller and S. Boss, 2015. Setting the standard for project-based learning: A proven approach to rigorous classroom instruction. Alexandria, VA: ACSD

[7] Carolie, Sly, 2015. A variety of teaching strategies based on students' levels of development and brain-based research. Center for Ecoliteracy 